\title{
THE EFFECT OF FINANCIAL PERFORMANCE OF COMPANIES ON SHARE RETURN IN MANUFACTURING COMPANIES LISTED IN INDONESIA STOCK EXCHANGE YEAR 2014 -2016
}

Paryanto $^{1}$, and N. Dicky Sumarsono ${ }^{2}$

Tax Management Study Program, STIE-AAS, Central Java, Indonesia paryanto.stieaas@gmail

\begin{abstract}
:This study aims to determine the effect of parsiil and simultaneous price book value, price earnings ratio, earnings per share and dividend pay out ratio to stock returns on manufacturing companies listed in Indonesia Stock Exchange 2014-2016. The technique of determining the sample in this research is by using purposive sampling. There are several criteria that must be met by companies listed in Indonesia Stock Exchange to be a sample in this research. This research method uses multiple regression analysis which is used to know the influence of independent variable to dependent variable together and partially. The test $t$ is used to test the influence of each price book value variable, price earning ratio, earnings per share and dividend pay out ratio) to stock return variables. Statistical test $\mathrm{F}$ aims to examine the influence of price book value variable, price earning ratio, earnings per share and dividend pay out ratio) together to stock return variables. Test R2 (Coefficient of determination) is done to find out how much influence the variable of price book value, price earning ratio, earnings per share and dividend pay out ratio to stock return variable. From result of $t$ test known that price book value, earnings per share and dividend pay out ratio partially significant effect to stock return. Variable Price Earning Ratio partially no significant effect on stock return variables. From result of $F$ test known that Price Book Value, Price Earning Ratio, Earning Per Share and Dividend Pay Out Ratio simultaneously have an effect on signifikan to variable Return of Shares In Manufacturing Company Listed In Indonesia Stock Exchange Year 2014 -2016.
\end{abstract}

Keywords : PBV, PER, EPS, DPR, Stock Return

\section{INTRODUCTION}

The purpose of the investor / company to invest is to earn a profit or return (return) large shares. The expected return of investors from an investment can be realized in the form of capital gains and dividends. Capital Gain is the amount of stock that can provide benefits for investors. Dividends represent a portion of the company's profits that the company distributes to its shareholders based on the number of shares held. Not all stock returns can be realized in the form of dividends because in a public company there is a policy called dividend policy.

In estimating the rate of return (rate of return) that will be obtained, investors first need to measure the company's financial performance. Financial performance will determine the high stock prices in the stock market. If the company's financial performance indicates a good prospect, 
then its shares will attract investors and the price increases. With rising stock prices of course stock returns received by investors also increased.

The analytical technique used to measure the company's financial performance in order to make long-term stock investment decisions is a fundamental analysis, which is an analytical technique that focuses on financial ratios.

From the analysis of financial ratios can be used to predict stock prices or returns in the capital market, including the financial condition of the company in the future.

According to Husnan (2009: 307) fundamental analysis predicts stock prices in the future by estimating the fundamental factors that affect future stock prices and connecting variables so that stock price estimates are known. Which in this study the author uses 5 variables, namely Price Book Value, Price Earning Ratio, Earning Per Share and Deviden Pay Out Ratio. These variables are the financial ratios to measure the company's financial performance in order to make long-term stock investment decisions.

Price to Book Value (PBV) is the ratio of stock price and book value per share of a company. This ratio illustrates how much the market appreciates the value of a company's stock book. The higher this ratio will give an idea that the higher stock price of the company, indicating the better performance of the company, so it can provide a better rate of return in the future. High price to book value reflects the level of prosperity of shareholders, where prosperity for shareholders is the main objective of the company.

Price Earning Ratio (PER) is the ratio used to measure the amount of money paid by the investor for each rupiah of corporate income. The high Price Earning Ratio (PER) of the company means the company's stock can provide a great return for investors, the greater the investor's confidence in the future of the company for the return of investment. Price Earning Ratio (PER) is used by investors to predict the company's ability to generate profit in the future. Investors can consider this ratio to sort out which stocks will benefit substantially in the future. PER denotes the relationship between the stock market price of the common stock and the earnings per share. A high level of profit signifies the growth of the company from the future. Companies with a high growth rate opportunity usually have a high PER, and vice versa companies with low growth have a small or low PER. PER is part of the market ratio where the viewpoint of this ratio is more from the investor's point of view and is also a measure to determine how the market assigns value or price to a company's stock.

Earning Per Share (EPS) represents the amount of profit earned for each common share. High EPS indicates that the company is able to provide a better level of welfare to shareholders. Thus EPS demonstrates the company's ability to earn profits and distribute profits to the shareholders.

Dividend payout ratio (DPR) is a comparison between dividends paid with the profits available to public shareholders (Hartono, 1998). Investors tend to like companies that have high levels of the House of Representatives because they are considered able to provide better benefits with better levels of certainty.

Given the company's financial performance analysis is needed in order to make investment decisions in stocks and given the high stock return of the company is very important of them will increase investor confidence to invest in a company hence the researcher interested to examine various factors affecting stock return of company with title: Effect of Financial Performance on Stock Return on Manufacturing 
Companies Listed In Indonesia Stock Exchange Year 2014 -2016.

\section{LITERATURE REVIEW}

\section{A. Theoretical Basis}

\section{Stock Return}

Stock return is one of the factors that encourage investors to invest and is a reward for the courage of investors to bear the risk of investment.

There are two types of returns: return realization (realized return) represents the return yng has occurred. This return is calculated using historical data. Return realization is important because it is used as a measure of the company's financial performance. Return realization is also useful in determining expected return and future risk. Return realization is measured by using total return, relative return, cumulative return and adjusted return. Medium average of return can be calculated based on arithmetic mean (mean arithmetc mean) and geometric mean (geometric mean). "The expected return is the expected return expected by investors in the future". Return of expectation can be calculated based on future expectation value, historical return value, expected return model. Jogiyanto Hartono (2008: 195)

The component of stock return as proposed by Tendelilin (2010: 48), states that the stock return consists of:

a. Capital gain (loss)

Capital gain (loss) is an increase (decrease) in the price of a stock that can provide profit (loss) for investors. Capital gain is also the result obtained from the difference between the purchase price (buying rate) and the selling price (the selling rate). This means that if the buying rate is less than the selling rate, the investor is said to get capital gain, and vice versa if the buying rate is greater than the selling rate, the investor will get capital loss. Then capital gains can be written as follows:

Capital Gain $($ Loss $)=(\mathrm{Pt}-\mathrm{Pt}-1) /(\mathrm{Pt}-1)$

Jogianto (2010)

Information:

$\mathrm{Pt}=$ Share price of current period

Pt-1 $=$ Stock price of previous period

\section{b. Yield}

Yield is a component of a return that reflects the cash flow or income derived periodically from a stock investment. Yield is also a percentage of periodic cash receipts on the investment price of a certain period of an investment, and for ordinary shares where periodic payments are Dt rupiah per share, the yield can be written as follows (Jogianto, 2010)

Yield $=$ Dt $/($ Pt-1)

Information:

$\mathrm{Dt}=$ cash dividends paid

Pt-1 $=$ Stock price of previous period

\section{Company Financial Statement Analysis}

In general, there are many analytical techniques in making investment judgments, but the most widely used are fundamental analysis, technical analysis, economic analysis, and financial ratio analysis (Anoraga, 2008).

According to Hanafi and Halim (2009) basically ratio analysis can be grouped into five kinds of categories, namely:

a. Liquidity Ratio

Ratio that measures a company's ability to meet its term obligations

in short. The liquidity ratio consists of: Current Ratio, Quick Ratio, and Net Working Capital.

\section{b. Activity Ratio}

This ratio indicates the company's ability to utilize its assets. The Activity Ratio consists of: Total Asset Turnover, Fixed Asset Turnover, Account Receivable Turnover, Inventory Turnover, Average Collection Period, and Day's Sales in Inventory. 
c. Solvency Ratio

This ratio shows the company's ability to meet its long-term obligations. The solvency ratio consists of: Debt Ratio, Debt to Equity Ratio, Long Term Debt to Equity Ratio, Long Term Debt to Capitalization Ratio, Times Interest Earned, Cash Flow Interest Coverage, Cash Flow Interest Coverage, Cash Flow to Net Income, and Cash Return on Sales.

d. Profitability Ratio

This ratio shows the ability of the company in generating profit. Revenue ratio consists of: Gross Profit Margin, Net Profit Margin, Return on Assets, Return on Equity, and Operating Ratio.

\section{e. Market Ratio}

This ratio indicates important company information and is disclosed on a per share basis. The market ratio consists of: Dividend Yield, Dividend Per Share, Dividend Payout Ratio, Price Earning Ratio, Earning Per Share, Book Value Per Share, and Price to Book Value.

Of the five ratios, which are directly related to the interest of stock return analysis include: Price to Book Value, Price Earning Ratio, Earning Per Share and Dividend Payout Ratio.

a. Price to Book Value

The existence of price book value is very important for investors to determine the investment strategy in the capital market because through price to book value, investors can predict overvalued or undervalued shares (Ahmed and Nanda, 2004). Price to Book Value (PBV) is the ratio of stock price and book value per share of a company. This ratio illustrates how much the market appreciates the value of a company's stock book. The higher this ratio will give an idea that the higher stock prices show the company's better performance, so it can provide a better rate of return in the future.

b. Price Earning Ratio

Price Earning Ratio is one of the largest sizes in fundamental stock analysis and part of the valuation ratio to evaluate financial statements.
Price earning ratio is useful to see how the market appreciates the performance of a company's stock on the performance of the company as reflected in earnings per share. According to Brigham and Houston (2010: 150), Price Earning Ratio is: The ratio of price per share to earnings per share indicates the amount that investors are willing to pay for each reported profit dollar.

A high PER indicates that investors are willing to pay a premium share price for the company. Based on the above opinion, the definition of PER referred to in this study is the ratio that compares the price of shares per share of common shares in circulation with earnings per share.

c. Earning Per Share

According to Brigham and Houston (2010: 240), earnings per share are

the amount of revenue earned in a given period for each number of shares outstanding.

This ratio is used to measure the percentage of earnings against stock prices. Earnings per share are the sum of the profits earned for each common share. High EPS indicates that the company is able to provide a better level of welfare to shareholders. Thus EPS demonstrates the company's ability to earn profits and distribute profits to the shareholders

d. Dividend Payout Ratio (DPR)

The dividend payout ratio determines the amount of profit that can be withheld as a source of funding. The greater the retained earnings the less the amount of profit allocated for dividend payments. According to Van Home et al (2009: 475), the ratio of dividend payout is the percentage of profit paid in dividend to the total profit available to shareholders. If the company cuts the dividend it will be considered a bad signal because it is considered the company needs funds. Therefore firms with high risks tend to have smaller DPRs so that they will not cut dividends if their profits fall. For high-risk firms, the probability of experiencing higher earnings 
decreases, as a result, investors tend to avoid stocks. This is different from the condition of companies that have high levels of DPR, investors tend to like this company because it is considered able to provide better benefits with a better degree of certainty.

\section{B. Previous Research}

The research will be conducted based on previous studies, namely:

First, research conducted by Nesa Anisa (2015) which aims to know the factors that influence stock return consisting of return on assets (ROA), current ratio (CR), debt to equity ratio (DER), price earning ratio PER) and price to book value (PBV). From the results of regression analysis obtained results partially (T-test) only variable ROA and DER have a significant effect on stock returns. Simultaneous test results (Ftest) shows that all independent variables simultaneously have a significant effect on stock returns.

Second, research conducted by Suriani Ginting (2013) on factor-faltor analysis that influences stock returns on manufacturing companies listed on the Indonesian stock exchange. The results showed that partially partially Price to Book Value (PBV) had an effect on Return of manufacturing company listed on Indonesia Stock Exchange period 2008 - 2011. While the change of operating profit, Net Profit Margin (NPM) and Price Earning Ratio PER) does not affect the Return of manufacturing companies listed on the Indonesia Stock Exchange period 2008 - 2011. While simultaneously changes in operating profit, Net Profit Margin (NPM), Price Earning Ratio (PER) and Price to Book Value (PBV) have a significant effect to Return of stock of manufacturing company listed in Indonesia Stock Exchange period 2008 - 2011.

Third, research conducted by Farda Eka Septiana (2016) about the influence of financial ratios seen from Return On Assets (ROA), Debt Equity Ratio (DER), Current Ratio (CR), Total Asset
Turnover (TAT) and Price Earning Ratio PER) on stock returns in food and beverage manufacturing companies in BEI period 20092014. F test results show that ROA, DER, CR, TATO, and PER variables simultaneously affect stock returns. Based on the results of partial analysis shows Debt Equity Ratio, Current Ratio significant effect on stock return, while Return On Asset, Total Asset Turnover and Price Earning Ratio no significant effect on stock return. The coefficient of determination of $52.2 \%$ means the variable of stock return change which can be explained by the variable ROA, DER, CR, TAT, PER of $52.2 \%$, while the rest of $47.8 \%$ is explained by other variables not included in this regression model.

Fourth, research conducted by Bambang Sudarsono (2016) about the factors that affect stock returns on property and real estate companies listed on the Indonesia Stock Exchange 2009 to 2014. Based on the results of the study known simultaneously together independent variable which consists of inflation, interest rates, Rupiah exchange rate against US Dollar, Return on Assets (ROA), Debt to Equity Ratio (DER) and firm size (size) can explain changes in stock returns. Partially, Inflation has significant negative effect on stock Return, Interest rate has positive significant effect on Return of stock, Rupiah exchange rate to US Dollar has positive significant effect on Return of Return, Return on Asset (ROA) has negative effect not significant to Return of stock, Debt to Equity Ratio (DER) has a significant negative effect on stock return, firm size (size) has a positive effect is not significant to stock return.

\section{Hypothesis}

1. Price Book Value, Price Earning Ratio, Earning Per Share And Dividend Pay Out Ratio jointly affect the Return of Stock On Manufacturing Companies Listed In Indonesia Stock Exchange Year 2014 -2016 
2. Price Book Value has a positive effect on Stock Return on Manufacturing Companies Listed In Indonesia Stock Exchange Year 2014 2016

3. Price Earning Ratio has a positive effect on Stock Return on Manufacturing Companies Listed In Indonesia Stock Exchange Year 2014 2016

\section{Thinking Framework}

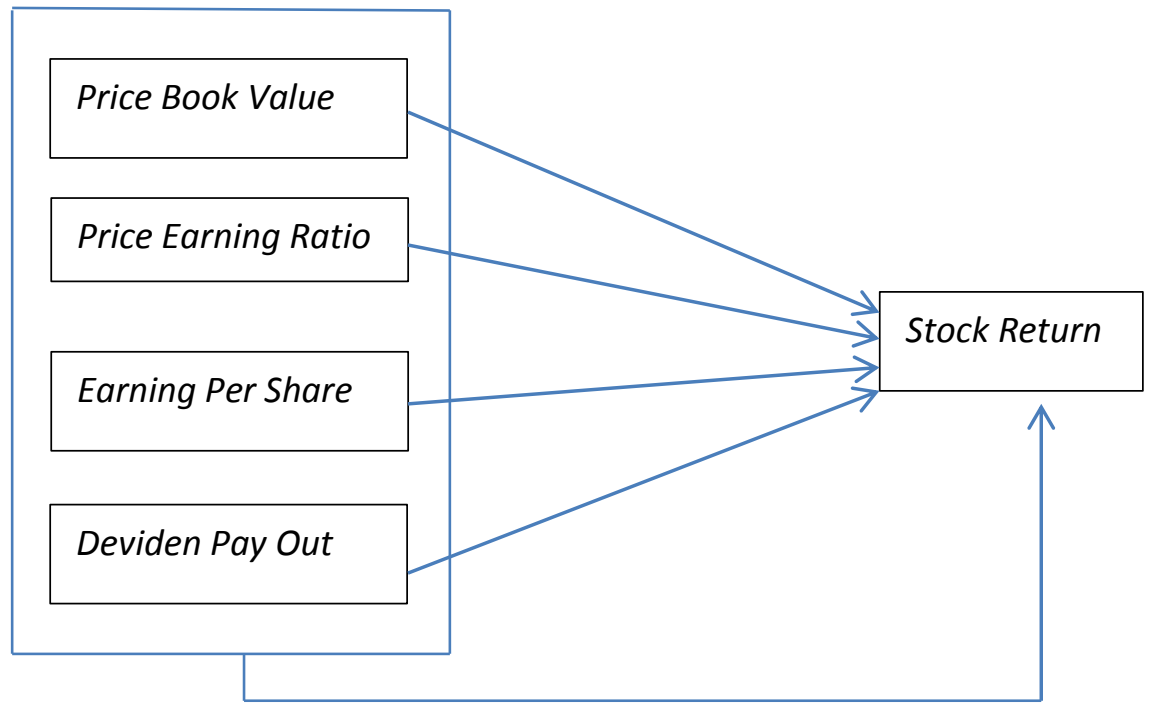

Figure 1. Framework for Thinking

\section{RESEARCH METHODOLOGY}

This study explains the relationship between variables by analyzing numerical data (numbers) using statistical methods through hypothesis testing, so this study is descriptive quantitative. This research is a case study research on manufacturing companies listed in Indonesia Stock Exchange 2014-2016.

\section{A. Data Source, Population, Sample, Data Collection Method}

The data required from this study consists of Annual Reports published by the company that became the object of research.
4. Earning Per Share has a positive effect on Stock Return on Manufacturing Companies Listed In Indonesia Stock Exchange Year 2014 2016

5. Deviden Pay Out positively affects Stock Return on Manufacturing Companies Listed In Indonesia Stock Exchange Year 2014 -2016 
a. Price Book Value

Price to Book Value (PBV) is the ratio of stock price and book value per share of a company. $\mathrm{PBV}=($ Price per share $) /($ book value per share $)$

\section{b. Price Earning Ratio}

Price earning ratio is the ratio that describes the comparison between stock price to earnings of company (Tandelilin, 2010). Mathematically the formula for calculating PER (price earning ratio) is:

Price Earning Ratio $=($ Per Share Per Share $) /$ (Revenue Per Share)

\section{c. Earning Per Share / Earnings Per Share}

Tandelilin (2001: 241) defines Earning Per Share (EPS) as the ratio between the amount of profit (in this case the net profit that is ready to be distributed to shareholders) with the number of shares outstanding.

Earnings Per Share $=($ Net Income $) /($ Number of Shares Circulated) Brigham and Houston (2006: 19)

\section{d. Deviden Payout Ratio}

According to Van Home et al (2009: 475), the ratio of dividend payout is the percentage of profit paid in dividend to the total profit available to shareholders. The dividend payout ratio determines the amount of profit that can be withheld as a source of funding.

$\mathrm{DPR}=($ Dividend per Share $) /$ (Earnings per Share) X $100 \%$

The technique of determining the sample in this research is by using purposive sampling. Criteria of companies incorporated in the Indonesia Stock Exchange period 2014-2016 listed on the Indonesia Stock Exchange (BEI) to be a sample in this study are:

Manufacturing companies listed on the Indonesia Stock Exchange (BEI) during the period of research is 2014-2016.

The Company periodically releases annual financial statements and has complete financial report data during the research period for the factors studied: Price Book Value, Price Earning Ratio, Earning Per Share and Deviden Pay Out Ratio.dan share return.

The company selected is a company that distributes its dividends annually to shareholders.

\section{Data Analysis Techniques}

\section{Data Quality Test}

\section{a. Normality test}

Normality test aims to test whether in the regression model, the dependent variable and the independent variable, both have a normal distribution or not. A good regression model is to have normal or near-normal data distribution. In this research, normality test data used statistical test Kolmograv Smirnov with criteria used is to compare significance value has been determined that is equal to $5 \%(0,05)$. If the probability value obtained is greater than 0.05 then the data is normally distributed.

\section{b. Autocorrelation Test}

The test done to detect this autocorrelation is Durbin Watson test. ie by comparing the value of Durbin Watson count (d) with its critical value or table value. If the value (d) lies between the upper bound (du) and (4-du), the autocorrelation coefficient is zero, meaning there is no autocorrelation.

\section{c. Multicollinearity Test}

This test is to test whether there is a linear relationship between independent variables in the regression model and to indicate whether there is a high degree of cholinearity among the independent variables. Multicolinearity test is done by looking at tolerance value and variance inflation factor (VIF). Commonly used values are tolerance values above 0.10 or with VIF values less than 10.

\section{d. Heterocedasticity Test}

Aimed to test whether in the regression model there is a variance inequality of the residual of a observation to another observation. To detect the occurrence of heteroskedastisitas in this study then used Spearman Rank Method by way of 
regretting the independent variables with residual variables which then correlated matrices. If the residual probability value is greater than $\alpha=$ 0.05 ; hence no symptoms of heteroskedastisitas vice versa if the value of residual is smaller than $\alpha=0.05$; then there will be symptoms of heteroscedasticity.

\section{Hypothesis Testing}

\section{a. Multiple Regression}

Multiple regression analysis is used to know the effect of free variable (Price Book Value, Price Earning Ratio, Earning Per Share and Deviden Pay Out Ratio) to dependent variable (Stock Return) together and partially. In this research the multiple regression equation is:

$\mathrm{Y}=\mathrm{a}+\mathrm{b} 1 \mathrm{X} 1+\mathrm{b} 2 \mathrm{X} 2+\mathrm{b} 3 \mathrm{X} 3+\mathrm{b} 4 \mathrm{X} 4+\mathrm{e}$ (Anto Dayan, 2000)

Where:

$\mathrm{Y}=$ Stock Return Variable

$\mathrm{X} 1=$ Price Book Value Variable

$\mathrm{X} 2$ = Variable Price Earning Ratio

X3 = Earning Per Share Variable

X4 = Variable Dividend Pay Out Ratio

a: constants

b: regression coefficient

e: error term

\section{b. Test-t}

This $t$ test is used to test the influence of each independent variable (Price Book Value, Price
Earning Ratio, Earning Per Share and Dividend Pay Out Ratio) to Share Return variable

\section{c. F-Test}

Statistical test $\mathrm{F}$ aims to test the influence of all independent or independent variables (Price Book Value, Price Earning Ratio, Earning Per Share and Deviden Pay Out Ratio) together to the dependent variable or bound (stock return).

\section{d. Coefficient of determination (R2)}

This test is conducted to find out how much influence of independent variables (Price Book Value, Price Earning Ratio, Earning Per Share and Deviden Pay Out Ratio) to the dependent variable (stock return).

\section{DISCUSSION}

\section{A. Data Analysis}

1. Classic Assumption Test

\section{a. Normality test}

Normality test was performed by Kolmogorov Smirnov test from the residual value of a regression model (Ghozali, 2005). Good data is normally distributed data. From the results of the Kolmogorof Smirnov normality test shown in Table 1 below shows the significance value of $1.1562>\alpha=0.005$ then the data is normally distributed

Table 1. Normality Test Results

One-Sample Kolmogorov-Smirnov Test

\begin{tabular}{|c|c|c|}
\hline & & $\begin{array}{l}\text { Unstandardized } \\
\text { Residual }\end{array}$ \\
\hline $\mathrm{N}$ & & 72 \\
\hline \multirow[t]{2}{*}{ Normal Parameters ${ }^{\mathrm{a}, \mathrm{b}}$} & Mean & .0000000 \\
\hline & Std. Deviation & .51247442 \\
\hline \multirow[t]{3}{*}{ Most Extreme Differences } & Absolute & .137 \\
\hline & Positive & .137 \\
\hline & Negative & -.063 \\
\hline Kolmogorov-Smirnov Z & & 1.162 \\
\hline Asymp. Sig. (2-tailed) & & .134 \\
\hline
\end{tabular}




\section{Vol-2, Issue-2, 2018 (IJEBAR)}

ISSN: 2614-1280, http://www.jurnal.stie-aas/ijebar

\section{b. Autocorrelation Test}

The term autocorrelation can be defined as the correlation between members of a series of observations sequenced by Gujarati (2001). A good regression model is a regression independent of autocorrelation. To determine whether there is autocorrelation symptoms in the regression calculation of this study, it will be used durbin watsen test (DW TES). The DW value of this study shows the number of 2.122 , where the number is between $\mathrm{du}=1,7366$ and 4$\mathrm{du}=2,2634$ it can be concluded there is no autocorrelation, then the model used in this study is feasible for basic analysis.

Table 2. Test Results Auto Correlation Durbin-Watson Method

\begin{tabular}{|l|r|r|r|r|r|}
\hline Model & \multicolumn{1}{|c|}{ Rodel Summary } \\
\hline 1 & $.477^{\mathrm{a}}$ & R Square & Adjusted R Square & $\begin{array}{c}\text { Std. Error of the } \\
\text { Estimate }\end{array}$ & Durbin-Watson \\
\hline
\end{tabular}

a. Predictors: (Constant), X4, X2, X1, X3

b. Dependent Variable: Y

\section{d. Heteroscedasticity test with Glejser test}

The purpose of the heteroscedasticity test to test whether in the regression model there is a variance inequality of the residual one observation to the other. If the variance of the residua one observation to another observation remains then it is called homoscedasticity. A good regression model is no heteroscedasticity. From table 3 value significance variable Price Book Value 0.010 , the significance of the variable Price Earning Ratio 0.142, variable Earning Per Share 0.015 and significance variable Deviden Payot Ratio 0,009. The significance value of the three independent variables namely Price Book Value, Price Earning Ratio and Earning Per Share is greater than $\alpha=0.05$ means that regression model does not occur heteroskedastisitas. While the value of variable significance Paydot Ratio smaller than $\alpha$ $=0.05$ means regression model occurs heteroskedastisitas.

Table 3. Heteroscedasticity Test Results

Coefficients ${ }^{\mathrm{a}}$

\begin{tabular}{|c|c|c|c|c|c|c|}
\hline \multirow{2}{*}{\multicolumn{2}{|c|}{ Model }} & \multicolumn{2}{|c|}{ Unstandardized Coefficients } & \multirow{2}{*}{$\begin{array}{c}\begin{array}{c}\text { Standardized } \\
\text { Coefficients }\end{array} \\
\text { Beta }\end{array}$} & \multirow[b]{2}{*}{$\mathrm{t}$} & \multirow[b]{2}{*}{ Sig. } \\
\hline & & B & Std. Error & & & \\
\hline \multirow[t]{5}{*}{1} & (Constant) & .039 & .094 & & .418 & .677 \\
\hline & $\mathrm{X} 1$ & .079 & .030 & .295 & 2.668 & .010 \\
\hline & $\mathrm{X} 2$ & -.001 & .001 & -.163 & -1.486 & .142 \\
\hline & $\mathrm{X} 3$ & .001 & .000 & .285 & 2.507 & .015 \\
\hline & $\mathrm{X} 4$ & -.009 & .003 & -.310 & -2.704 & .009 \\
\hline
\end{tabular}

a. Dependent Variable: Y 


\section{Vol-2, Issue-2, 2018 (IJEBAR)}

ISSN: 2614-1280, http://www.jurnal.stie-aas/ijebar

\section{d. Multicolinearity Test}

The purpose of multicollinearity test is to know whether the regression model found a correlation between independent variables (independent). A good model should not have a correlation between independent variables (no multicolonierity).

If the VIF value is less than 10 , then there is no multicollinearity to the data being tested. Conversely, if the VIF value is greater than 10, it means multicollinearity to the data being tested.
From the results of multicollinearity test in table 4 VIF value of the four independent variables is smaller than 10 so it can be said that there is no multicollinearity model among these variables.

From the results of multicollinearity test obtained the tolerance value of the four independent variables greater than 0.1 so it can be said that there is no multicollinearity model among variables.

Table 4. Multicollinearity Test Results Coefficients $^{\mathrm{a}}$

\begin{tabular}{|c|c|c|c|c|c|c|c|}
\hline \multirow[b]{2}{*}{ Model } & \multicolumn{2}{|c|}{ Unstandardized Coefficients } & \multirow{2}{*}{$\begin{array}{c}\begin{array}{c}\text { Standardized } \\
\text { Coefficients }\end{array} \\
\text { Beta }\end{array}$} & \multirow[b]{2}{*}{$\mathrm{t}$} & \multirow[b]{2}{*}{ Sig. } & \multicolumn{2}{|c|}{ Collinearity Statistics } \\
\hline & $\mathrm{B}$ & Std. Error & & & & Tolerance & VIF \\
\hline 1 (Constant) & .039 & .094 & & .418 & .677 & & \\
\hline $\mathrm{X} 1$ & .079 & .030 & .295 & 2.668 & .010 & .941 & 1.063 \\
\hline $\mathrm{X} 2$ & -.001 & .001 & -.163 & -1.486 & .142 & .955 & 1.047 \\
\hline $\mathrm{X} 3$ & .001 & .000 & .285 & 2.507 & .015 & .893 & 1.119 \\
\hline $\mathrm{X} 4$ & -.009 & .003 & -.310 & -2.704 & .009 & .875 & 1.143 \\
\hline
\end{tabular}

a. Dependent Variable: $\mathrm{Y}$

\section{Hypothesis Testing}

\section{a. Multiple Linear Regression Equation}

Based on the calculation of SPSS that appear in table 5 regression equation as follows:

$\mathrm{Y}=0.039+0.079 \mathrm{PBV}-0.001 \mathrm{PER}+0.001 \mathrm{EPS}$ $-0.009 \mathrm{DPR}+\mathrm{e}$

From the regression equation it can be seen that the independent variables that have a positive effect on stock return is Price Book Value with coefficient of 0.079 and Earning Per Share with coefficient 0.001. This means that when Price Book Value, and Earning Per Share increase then the stock return of the company also increased. While the independent variables that have a negative effect on stock return is Price Earning Ratio with coefficient 0.001 and Deviden Payout Ratio with coefficient 0.009 . This means that when the Price Earning Ratio and Deviden Payout Ratio decreases then the company's stock return increases and vice versa.

\section{b. Individual Parameter Significant Test (Test -t Statistic)}

The $t$ test is used to know the partial significance of the independent variables: Price Book Value (X1), Price Earning Rati (X2), Earning Per Share (X3) and Deviden Payout Ratio (X4) to dependent variable: Return of company $\mathrm{Y}$ ).

From table 5 is known magnitude influence of each independent variable to the dependent variable is as follows:

1) Test the hypothesis of the influence of Price Book Value on stock return of the company. From result of calculation of $t$ significance for Price Book Value variable equal to 0,010 smaller 
than $\alpha(0,05)$. This means that Price Book Value in parsiil significant effect on stock return company.

2) Test the hypothesis Price Earning Ratio to stock return company.

From result of calculation, significance $t$ for

Price Earning Ratio variable equal to 0,142 bigger than $\alpha(0,05)$. This means that Price Earning Ratio has no significant effect on stock return of company.

3) Test the Earning Per Share hypothesis on stock return of company
From the calculation results obtained significance $t$ for the variable Earning Per Share of 0.015 is smaller than $\alpha(0.05)$. It means that Earning Per Share has significant effect to stock return.

4) Test the hypothesis of Deviden Payout Ratio to stock return of company

From the calculation results obtained significance $\mathrm{t}$ for the variable deviden Payout Ratio of 0.009 smaller than $\alpha(0.05)$. This means that the dividend payout ratio has a significant effect on stock return.

Table 5. Multiple Linear Regression and Test Result t Coefficients $^{\mathrm{a}}$

\begin{tabular}{|c|c|c|c|c|c|c|}
\hline \multirow{2}{*}{\multicolumn{2}{|c|}{ Model }} & \multicolumn{2}{|c|}{$\begin{array}{c}\text { Unstandardized } \\
\text { Coefficients }\end{array}$} & \multirow{2}{*}{$\begin{array}{c}\begin{array}{c}\text { Standardized } \\
\text { Coefficients }\end{array} \\
\text { Beta }\end{array}$} & \multirow[b]{2}{*}{$\mathrm{t}$} & \multirow[b]{2}{*}{ Sig. } \\
\hline & & B & Std. Error & & & \\
\hline \multirow[t]{5}{*}{1} & (Constant) & .039 & .094 & & .418 & .677 \\
\hline & $\mathrm{X} 1$ & .079 & .030 & .295 & 2.668 & .010 \\
\hline & $\mathrm{X} 2$ & -.001 & .001 & -.163 & -1.486 & .142 \\
\hline & $\mathrm{X} 3$ & .001 & .000 & .285 & 2.507 & .015 \\
\hline & X4 & -.009 & .003 & -.310 & -2.704 & .009 \\
\hline
\end{tabular}

a. Dependent Variable: $\mathrm{Y}$

level of 0.001 . The resulting significance value

\section{c. Test F}

From the results of statistical calculations using SPSS which appears in table 6 obtained F calculated value of 4.940 with a significance of $F$ is smaller than $\alpha=0.05$. This means that the variable of Price Book Value, Price Earning Ratio, Earning Per Share, and variable of Deviden Payout Ratio simultaneously have a significant effect to company stock return variable.

Table 6. Test Result F ANOVA $^{\text {b }}$

\begin{tabular}{|c|c|c|c|c|c|c|}
\hline \multicolumn{2}{|c|}{ Model } & Sum of Squares & df & Mean Square & $\mathrm{F}$ & Sig. \\
\hline 1 & $\begin{array}{l}\text { Regressi } \\
\text { on }\end{array}$ & 5.499 & 4 & 1.375 & 4.940 & $.001^{\mathrm{a}}$ \\
\hline & Residual & 18.647 & 67 & .278 & & \\
\hline & Total & 24.146 & 71 & & & \\
\hline
\end{tabular}

a. Predictors: (Constant), X4, X2, X1, X3

b. Dependent Variable: Y 
Table 7. Result Test R2

\begin{tabular}{|l|l|r|r|r|}
\hline Model & \multicolumn{1}{|c|}{ R } & R Square & $\begin{array}{c}\text { Adjusted R } \\
\text { Square }\end{array}$ & $\begin{array}{c}\text { Std. Error of } \\
\text { the Estimate }\end{array}$ \\
\hline 1 & $.477^{\mathrm{a}}$ & .228 & .182 & .527550 \\
\hline
\end{tabular}

a. Predictors: (Constant), X4, X2, X1, X3

From the results of calculations with SPSS program that appears in table 7 can be seen that the coefficient of determination that can be seen from R Square, obtained by 0.228 . This means that only $22.8 \%$ of company stock return can be

\section{B. Discussion}

Individual test result using $\mathrm{t}$ test is obtained that variable that is Price Book Value, Earning Per Share and Deviden Pay Out Ratio have significant effect to stock return of manufacturing companies listed in Indonesia Stock Exchange year 2014-2016. Individual test results using $t$ test found that the variable Price Earning Ratio does not significantly affect the stock return of the company.

The results of this study indicate Price Book Value significant effect on stock returns of manufacturing companies listed on the Indonesia Stock Exchange 2014-2016. The results of this study can be assumed that the market appreciates the book value of shares of manufacturing companies listed on the Indonesia Stock Exchange 2014-2016 which also means market confidence in the future prospects of the company is also high. So that investors take the The results of this study states Price Earning Ratio does not significantly affect the stock return of manufacturing companies that list on the Indonesia Stock Exchange 2014-2016. This can be assumed even though the Price Earning explained by Price Book Value variable, Price Earning Ratio, Earning Per Share and Deviden Pay Out Ratio in this study, while the remaining $77.2 \%$ is explained by other variables not examined in research this.

decision to invest in a manufacturing company listed on the Indonesia Stock Exchange 20142016. With the increasing number of companies investing in manufacturing companies, the higher the stock price. The higher the stock price will be the higher stock return also.

The results of this study are in line with research conducted by Suriani Ginting which states Price Book Value has a significant effect on stock returns of manufacturing companies listed on Indonesia Stock Exchange 2008 - 2011.

The results of this study are not in line with research conducted Nesa Anisa which states Price Book Value does not significantly affect the stock return of companies in manufacturing companies listed on the Indonesia Stock Exchange.

Ratio of manufacturing companies incorporated in the Indonesia Stock Exchange 2014-2016 increases but not followed by increasing investor confidence in the future of the company so as not to trigger an increase in stock price of 
manufacturing companies listed on the Indonesia Stock Exchange 2014-2015 . So if the price per share does not increase / decrease and the rate of profit growth of a company also does not increase, then Price Earning Ratio also decreased and stock return will also decrease.

The results of this study are in line with research conducted Nesa Annisa which states Price Earning Ratio (PER) has no effect on Return of manufacturing companies listed on the Indonesia Stock Exchange period 2008 - 2011. The results of this study is also in line with research conducted by Suriani Ginting which states Price Earning Ratio (PER) does not affect the Return of manufacturing companies listed on the Indonesia Stock Exchange period 2008 - 2011. The results of this study is also in line with research conducted Farda Eka Septiana which states Price Earning Ratio does not significantly affect the stock returns on manufacturing sector companies food and baverage contained in BEI period 2009-2014.

The results of this study states that the Earning per Share (EPS) has a significant effect on stock returns of manufacturing companies listed in Indonesia Stock Exchange 2014-2016. The results of this study can be assumed that the level of profit per share of manufacturing companies listed on the Indonesia Stock Exchange 20142016 is relatively large, thus increasing the interest of investors to invest their shares in the manufacturing sector.

The results of this study are not in line with research conducted by Desy Arista which states Earning Per Share (EPS) has no significant effect on stock returns of manufacturing companies listed on the Indonesia Stock Exchange. The results of this study are also not in line with research conducted by Jullie Sondakh, Winston Pontoh, and Steven Tangkuman which states Earning Per Share (EPS) has no significant effect on stock returns of manufacturing companies listed on the Indonesia Stock Exchange during the year 2006-2010.

The results of this study states menyataka Deviden Payout Ratio significant effect on stock return of manufacturing companies that list on the Indonesia Stock Exchange 2014-2016. The results of this study can be assumed that the higher the value of House of Representatives manufacturing companies listed on the Indonesia Stock Exchange resulted in increased value of shares of the company and investors will get certainty about the distribution of better dividends on investment. This is able to increase demand for these shares, resulting in an increase in stock prices, as well as impact on a positive return.

The result of this research is in line with the research conducted by Riawan who stated that the dividend policy has significant effect on stock returns in the company incorporated in Islamic Index Jakarta listed on Indonesia Stock Exchange for 2010-2013 period.

The results of this study are also in line with research conducted by Michael Aldo Carloyang declared House of Representatives positive and significant effect on stock returns in companies listed in the LQ45 index 2010-2012.

\section{CONCLUDES AND SUGGESTIONS}

\section{A. Conclusion}

The conclusions of this study are as follows:

1. Price Book Value has a positive and significant effect on stock returns of manufacturing companies listed on the Indonesia Stock Exchange 2014-2016. This shows that the market appreciates the value of share book of manufacturing companies listed on the Indonesia Stock Exchange in 2014-2016, which also means that market confidence in the future prospects is also high. So that investors take the decision to 
invest in a manufacturing company listed on the Indonesia Stock Exchange 2014-2016. With the increasing number of companies investing in manufacturing companies, the higher the stock price. The higher the stock price will be the higher stock return also.

2. Price Earning Ratio has a negative effect, not significant to the stock return of manufacturing companies listed on the Indonesia Stock Exchange 2014-2016. This shows that the Price Earning Ratio of manufacturing companies incorporated in the Indonesia Stock Exchange 2014-2016 increase but not followed by increasing investor confidence in the future of the company so as not to trigger an increase in stock price of manufacturing companies listed on the Indonesia Stock Exchange 2014-2016. So if the price per share does not increase / decrease and the level of corporate earnings growth also did not increase, then Price Earning Ratio also decreased and stock return will also decrease.

3. Earning Per Share have a significant positive effect on stock returns of manufacturing companies listed on the Indonesia Stock Exchange 2014-2016. This can be interpreted as the level of profit per share of manufacturing companies listed on the Indonesia Stock Exchange 2014-2016 increased, thus increasing the interest of investors to invest their shares in manufacturing companies listed on the Indonesia Stock Exchange 2014-2016. Increased investor interest to invest their shares in the company resulted in rising stock prices and then followed by increased stock returns.

4. Deviden Pay Out Ratio has a significant negative effect on stock returns of manufacturing companies listed on the Indonesia Stock Exchange 2014-2016. The results of this study can be assumed by the increase of Deviden
Payout Ratio of manufacturing companies that list in Indonesia Stock Exchange 2014-2016 year does not necessarily increase investor confidence also. The rise of the House of Representatives is not followed by the increasing demand for the company's shares, so the stock price does not increase as well, and also the effect on the stock return of manufacturing companies that listed in Indonesia Stock Exchange 2014-2016.

5. Price Book Value, Price Earning Ratio, Earning Per Share, and variable Dividend Payout Ratio simultaneously have a significant effect on stock return.

6. Return of company stock can be explained by Price Book Value variable, Price Earning Ratio, Earning Per Share and Deviden Pay Out Ratio only equal to $22,8 \%$, while rest $77,2 \%$ explained by other variable not examined in this research.

\section{B. Suggestions}

1. For investors who want to invest in manufacturing companies listed on the Indonesia Stock Exchange is expected to consider other factors that may affect stock returns, because the results of this study indicate that the contribution of variables PBV, PER, EPS and DPR in explaining stock returns relatively small.

2. In order for the stock returns of manufacturing companies to increase, it is expected that manufacturing companies can improve their financial performance so as to provide more returns to investors. High stock returns are expected to increase investor confidence to invest in manufacturing companies.

3. For further researcher is suggested to add research variables that can affect stock return and add a longer time range so that later expected results will be more generalizable. 


\section{Reference}

Ahmed and Nanda. 2004. Style Investing: Incorporating PBV in Value Stocks. The Journal of Portfolio Management

Anoraga, Banners and Piji Pakarti. 2008. Introduction to Capital Markets. Printed 3. Jakarta: Rineka Cipta.

Anto Dajan. 2000. Introduction to Statistical Methods. Volume I, II, Jakarta: LP3ES.

Basuki, Sulistyo. 2006. Research Methods. Jakarta: Wedatama Widya Sastra.

Brigham and Houston. 2010. Fundamentals of Financial Management Books 1. Issue 11. Jakarta: Salemba Four.

Desy Arista. Analysis of Factors - Factors That Influence Stock Return (Case On Manufacturing Companies Which Go Public In Bei Period Year 2005 - 2009). Journal of Management Science and Applied Accounting. Vol 3. Number 1. May 2012.

Farda Eka Septiana. The Influence of Financial Ratios On Stock Return In Manufacturing Companies. Journal of Management Science and Research: Volume 5. Number 1. January 2016.

Ginting, Suriani. Factor-Faltor Analysis Which Affects Stock Return In Manufacturing Companies Listed In Indonesia Stock Exchange. Journal of Mikroskil Economic Entrepreneurs. Volume 3. Number 01. April 2013.

Ghozali, Imam. 2011. Application of Multivariate Analysis With SPSS Program. Semarang: Diponegoro University Publishing Agency.

Gujarati, D., 1991. Basic Econometrics. Sumamo Zain Translation. Jakarta: Erland.
Halim, Abdul and Mamduh M. Hanafi. 2009. Financial Statement Analysis. Edition 4. Yogyakarta: UPP STIM YKPN.

Hartono, Jogiyanto. 2008. Portfolio Theory And Investment Analysis. Yogyakarta: BPFE.

Horne James C. Van and John M.Wachowicz. 2009. Principles of Financial Management. instead of Dewi Fitriasari and Deny A.Kwary. Jakarta: Salemba.

Jullie Sondakh, Winston Pontoh, and Steven Tangkuman. Influence of Financial Ratios on Stock Returns In Manufacturing Companies In Indonesia Stock Exchange. LPPM Journal of EkoSosBudKum Field. Volume 1. Number 1. Year 2014

Michael Aldo Carlo. Effect of Return On Equity, Dividend Payout Ratio, And Price To Earnings Ratio On Stock Return. E-Journal of Accounting. Udayana University 7.1 2014.

Nawawi, Hadari. 2012. Social Research Methods. Yogyakarta: Elephant. Mada University Press. 